\title{
Original article: \\ The Effect of Religious Relaxation Therapy on Improving Sleep Quality of Patients Chronic Kidney Failure: A Pilot Study in Surabaya \\ Rini Purwanti ${ }^{1}$, Ah.Yusuf ${ }^{2}$, Hanik Endang 3 , Siti Nur Qomariah ${ }^{4}$, Abu Bakar $^{5}$
}

\begin{abstract}
:
Objective: It is discovered that approximately $80 \%$ patients with chronic kidney failure undergoing haemodialysis treatment experience a difficulty to sleep. Such issue could decrease the patients' living quality. The relaxation therapy using spiritual approach based on the patients' religion to improve sleep quality has not been scientifically proven yet. This study aims to analyze the effect of religious relaxation therapy on patients with chronic kidney failure undergoing haemodialysis treatment. Materials and methods: The research was quasy experiment with prepost test control group design. The subjects of the research are the entire patients with chronic kidney failure who undergo haemodialysis treatment in the Islamic Hospital. The samples are taken from sixty clients recruited by random sampling allocation technique. Those clients aged 20-65 years old, Moslem and no complications. Patients' sleeping quality is determined by The Pittsburgh Sleep Quality Index (PSQI). Meanwhile, the data is analyzed by using Wilcoxon sign rank statistic test and Mann Whitney U test. Results and Discussion: The research showed that the religious relaxation therapy is proven to have a more improved good sleep quality $(73.3 \%)$ while the control group tends to be stagnant. The religious therapy is proven to have a positive effect on sleep quality by $\mathrm{p}=0.000$ Conclusion: The religious relaxation therapy gives positive effects in improving the sleep quality for patients with chronic kidney failure who undergo haemodialysis treatment.
\end{abstract}

Keyword: Chronic kidney failure; Religious relaxation therapy; Sleep quality; Haemodialysis

Bangladesh Journal of Medical Science Vol. 19 No. 01 January'20. Page : 48-52 DOI: https://doi.org/10.3329/bjms.v19i1.43872

\section{Introduction}

It has been commonly known that trouble of sleep happens to most patients undergoing haemodialysis 1. For the patients with chronic kidney failure, the rate of such trouble could go as high as $50-80 \%{ }^{2}$. It could lead to a decreasing productivity for patients in doing their daily routine and a degrading quality of their health as well, which could increase the rate of patient suffering illness and death ${ }^{3}$. Therefore, such condition is in need to be resolved. The most common methods to overcome this issue are by applying pharmacological and non-pharmacological therapy. The former one, however, might need to be limited for patients with chronic kidney failure due to the possibility of distracting either the function of kidney itself or haemodialysis process ${ }^{4}$.. Meanwhile, the latter form of therapy can be given to them by improving biofeedback, sleep hygiene,

1. Rini Purwanti, S.Kep., Department of Urology, Dr. Soetomo Hospital, Surabaya, Indonesia, Email: rini. purwanti81@gmail.com

2. Dr. Ah. Yusuf, S.Kp., M.Kes. Faculty of Nursing, Airlangga University, Surabaya, Indonesia. Email: ahyusuf@fkp.unair.ac.id

3. Dr. Hanik Endang Nihayati, S.Kep., Ns., M.Kep, Faculty of Nursing, Airlangga University, Surabaya, Indonesia. Email: azzam_psik@yahoo.com

4. Siti Nur Qomariah, S.Kep., Ns., M.Kep, Faculty of Health Science, Gresik University, Gresik, Indonesia. Email: snurq18@gmail.com.

5. Dr. Abu Bakar, M.Kep., Ns.Sp.Kep.M.B. Faculty of Nursing, Airlangga University, Surabaya, Indonesia. Email: abu.bakar@fkp.unair.ac.id

Correspondence to: Dr. Abu Bakar, M.Kep., Ns.Sp.Kep.M.B, Department of Medical Surgical Nursing, Faculty of Nursing, Airlangga University, Mulyorejo Road, C Campus, Surabaya, East Java, 60115, Indonesia.Email: abu.bakar@fkp.unair.ac.id 
cognitive therapy and relaxation technique ${ }^{6}$.

This research is related to relaxation technique to decrease the anxiousness and distress effectively ${ }^{7}$. Such technique has been developed to a religious relaxation, which is a combination of relaxation and the religion they believe in ${ }^{8}$. Furthermore, other supporting researches has shown that such technique needs to be adjusted with the patients cultural and religious background in order that they will be able to gain its benefit effectively ${ }^{9}$. The effect of this relaxation technique on previous study has not been explained in details. Thus, this research is focusing on religous relaxation therapy to the improving quality of sleep chronic kidney failure clients.

\section{Materials and methods}

Design:

The research is designed by using Quasy Experiment along with pre-post test control group design. The subjects of the experiment will be divided into two groups, religous relaxation therapy and control group. The patients in the first group will be taken care of by applying religious relaxation therapy while the latter one was given a standard hospital therapy. Religious relaxation therapy were applied to the patients for two days. They were trained for doing such relaxation therapy based on the booklet available, which includes preparation before sleeping, relaxation technique and saying prayers as apart of the ritual. The patients involved in this therapy every night before sleeping in fourteen days, and once in three days for strengthening therapy. Those two groups will be observed focusing on their sleep quality before and after intervention. The research statement is the effect of religious relaxation technique on the sleep quality for patients undergoing haemodialysis with chronic kidney failure.

Sample:

The sample data for this experiment is taken from the patients undergoing haemodialysis with chronic kidney failure who have issues in sleep quality. There were 60 patients recruited by allocation random sampling technique. Such technique was given to the patients in the intervention group, who underwent haemodialysis on Mondays and Thursdays. Meanwhile, the patients in the control group would be given on Tuesdays and Fridays. Next, the allocation random sampling was applied. The data was collected accordingly based on the patient's criteria, which includes undergoing haemodialysis regularly twice a week for the past three months, within the age 20-65 years old, Moslem, and without any complications in their lung and heart. The data collection had been done in two months, during November-December 2017.

Research instrument:

The variable for sleep quality is determined by using The Pittsburgh Sleep Quality Index (PSQI) questionnaire. It includes seven aspects or domain in it such as subjective sleep quality, sleep latency, duration of sleep, distractions while sleeping at night, the sleeping pills consumption and distraction on routines during the daylight. The original version of PSQI questionnaire was designed in English by Buysse, Reynolds, Monk, Berman and Kupfer back in $1989^{10}$. Such questionaire has been proven for its internal consistency and coeficient of reliability (Cronbach's Alpha 0.83) for its component ${ }^{11}$. Meanwhile, its Indonesian version has been used for other research and proven for its vailidity and reliability ${ }^{12,13}$.

Data analysis:

All data is analyzed by considering frequency and percentage. Main data analysis is done by the two statistic tests, Wilcoxon Signed Rank Test and Mann Whitney U Test with level of significance $\rho \leq 0.05$.

\section{Ethical clearance:}

The research procedure has been examined and regarded properly used by The Committee of Ethics on November 2nd, 2017 legalized by the official letter of accordance number 073/49/KOM. ETIK/2017. The principle of ethic applied in this research is that the respondents were informed and filled in the informed consent agreement before data collection process. They have the rights to have their data remain confidential and only be published by their initials only.

\section{Results}

The result of data collection shows the details of research subjects in table 1 . There is a difference in terms of gender dominance in each group. The intervention group mostly consists of females, while the control group mostly consists of males. The research subjects are within the age of 4665 years old. In addition, the intervention group undergo haemodialysis for 3-5 years whereas the control group undergo haemodialysis for 1-3 years. Same characteristic between two groups have rather negative habit before sleeping, watching TV. 
Table 2 The Patient's Sleep Quality (N=60)

\begin{tabular}{|c|c|c|c|c|c|}
\hline \multirow[b]{2}{*}{ Measure } & \multicolumn{2}{|c|}{ Contro Group } & \multicolumn{2}{|c|}{ Intervention Group } & \multirow{2}{*}{$\begin{array}{c}\text { Mann Whitney U Tes } \\
\text { ( } \rho \text { value) }\end{array}$} \\
\hline & $\begin{array}{c}\text { Pre Test } \\
\mathrm{n}(\%)\end{array}$ & $\begin{array}{c}\text { Post Test } \\
\mathrm{n}(\%)\end{array}$ & $\begin{array}{c}\text { Pre Test } \\
\mathrm{n}(\%)\end{array}$ & $\begin{array}{c}\text { Post Test } \\
\mathrm{n}(\%)\end{array}$ & \\
\hline $\begin{array}{l}\text { Sleep Quality } \\
\text { a. Bad } \\
\text { b. Good }\end{array}$ & $\begin{array}{l}30(100) \\
0(0)\end{array}$ & $\begin{array}{l}30(100) \\
0(0)\end{array}$ & $\begin{array}{l}30(100) \\
0(0)\end{array}$ & $\begin{array}{l}8(26.7) \\
22(73.3)\end{array}$ & $(0.000)$ \\
\hline $\begin{array}{l}\text { Wilcoxon Signed Rank Test } \\
\text { ( } \rho \text { value })\end{array}$ & \multicolumn{2}{|c|}{$(0.102)$} & \multicolumn{2}{|c|}{$(0.000)$} & - \\
\hline
\end{tabular}

\section{Acknowledgments:}

We would like to acknowledge all of the participants, nurse, and other hospital staff who cooperated in the present study.

\section{Conflict of interest}

We have no conflicts of interest to disclose

\section{Authors Contribution}

Rini Purwanti, Ah.Yusuf, Abu Bakar, and Hanik Endang were participated in performing the concept

\section{References:}

1. Afshar R, Emany A, Saremi A, Shavandi N, Sanavi S. Effects of intradialytic aerobic training on sleep quality in hemodialysis patients. Iran J Kidney Dis. 2011;5(2):119123. doi:360/272 [pii].

2. Sabry AA, Abo-Zenah H, Wafa E, et al. Sleep disorders in hemodialysis patients. Saudi J Kidney Dis Transpl. 2010;21(2):300-305. doi:10.3732/ajb.0800250.

3. Collins AJ, Foley RN, Gilbertson DT, Chen S. The state of chronic kidney disease, ESRD, and morbidity and mortality in the first year of dialysis. In: Clinical Journal of the American Society of Nephrology. Vol 4. ; 2009. doi:10.2215/CJN.05980809.

4. Zafari M, Aghamohammady A, Mosavy M. Renal function in Thalassemia major patients who treated by Desferal. Bangladesh J Med Sci. 2018;17(1):58-61. doi:http://dx.doi.org/10.3329/bjms.v17i1.35281.

5. St. Peter WL. Improving Medication Safety in Chronic Kidney Disease Patients on Dialysis Through Medication Reconciliation. Adv Chronic Kidney Dis. 2010;17(5):413-419. doi:10.1053/j.ackd.2010.06.001.

6. Potter P, Perry A, Stockert P, Hall A. Fundamentals of Nursing. 8th ed. St. Louis Missouri: Mosby Elsevier; 2012.

7. Tetti S, Yeni R. The Reduction of Anxiety level with Benson Relaxation at Cibabat Cimahi Hospital. GSTF $J$ Nurs Heal Care ( JNHC). 2014;1(2):167-171. doi:10.5176/2345-718X.

8. Joshi S, Kumari S, Jain M. Religious Belief and Its theory, wrote the introduction, methodology (research sample, developing research instruments), results, discussion and conclusion, each part written by any of the authors was reviewed and edited by the other authors. Rini Purwanti were responsible for selecting the study sample, and collecting the data. Abu Bakar and Siti Nur Qomariah helped in the content analysis and manuscript.

Relation to Psychological Well-being. J Indian Acad Appl Psychol. 2008;34(2):345-354.

9. Momennasab M, Moattari M, Abbaszade A, Shamshiri B. Spirituality in survivors of myocardial infarction. Iran J Nurs Midwifery Res. 2012;17(5):343-351.

10. Buysse DJ, Reynolds CF, Monk TH, et al. The Pittsburgh Sleep Quality Index: a new instrument for psychiatric practice and research. Psychiatry Res. 1989;28(2):193213. doi:10.1016/0165-1781(89)90047-4.

11. Azri MA, Dahlan A, Masuri MG, Anuar K. Sleep Quality among Older Persons in Institutions. Procedia - Soc Behav Sci. 2016;234:74-82. doi:10.1016/j. sbspro.2016.10.221.

12. Alim IZ. Test validity and reliability of the instrument pittsburgh sleep quality index Indonesia language version. 2015. http://lib.ui.ac.id/detail?id=20404062\&lo kasi=lokal.

13. Fandiani YM, Wantiyah, Juliningrum PP. The Effect of Dzikir Therapy on Sleep Quality of College Students at School of Nursing University of Jember. Nurseline J. 2017;2(1):52-60.

14. Rambod M, Rafii F, Hosseini F. Quality of Life in Patients with End Stage Renal Disease. tums-hayat. 2008;14(2):51-61. http://hayat.tums.ac.ir/article-1-147en.html.

15. Tribl GG, Schmeiser-Rieder A, Rosenberger A, et al. Sleeping habits in the Austrian population. Sleep Med. 2002;3(1):21-28. doi:10.1016/S1389-9457(01)00117-4.

16. Hmwe NTT, Subramanian P, Tan LP, Chong WK. The 
effects of acupressure on depression, anxiety and stress in patients with hemodialysis: A randomized controlled trial. Int J Nurs Stud. 2015;52(2):509-518. doi:10.1016/j. ijnurstu.2014.11.002.

17. Nag C, Pradhan RK. Impact of television on sleep habits. Biol Rhythm Res. 2012;43(4):423-430. doi:10.1080/092 91016.2011.599630.

18. Lawrence G, Muza R. Assessing the sleeping habits of patients in a sleep disorder centre: a review of sleep diary accuracy. J Thorac Dis. 2018;10(S1):S177-S183. doi:10.21037/jtd.2017.12.127.

19. Shariati A, Jahani S, Hooshmand M, Khalili N. The effect of acupressure on sleep quality in hemodialysis patients. Complement Ther Med. 2012;20(6):417-423. doi:10.1016/j.ctim.2012.08.001.

20. Noghani F, Mohtashemi J, Vasegh Rahimparvar F, Babaei G. Effect of education of religious values on the rate of depression. tums-hayat. 2005;10(4):49-56. http:// hayat.tums.ac.ir/article-1-248-en.html.

21. MOHAMED, Mahmood Nazar; MARICAN, S. Treatment and Rehabilitation of Substance Use Disorder: Significance of Islamic Input in Malaysia. International Journal of Human and Health Sciences (IJHHS), 2018; 2(4), p. 209-216. doi:http://dx.doi.org/10.31344/ijhhs. $\mathrm{v} 2 \mathrm{i} 4.57$.

22.AHMAD, Wafa 'a Qasem. Spiritual Care at The End OfLife: Western Views and Islamic Perspectives. International Journal of Human and Health Sciences (IJHHS), 2018; 2(2), p. 65-70. doi:http://dx.doi.org/10.31344/ijhhs. v2i2.28.

23. Permana I. How Religosity and/or Spirituality Might Influence Self-Care in Diabetes Management : A Structured Review. Bangladesh J Med Sci. 2018;17(2):185-193. doi:http://dx.doi.org/10.3329/ bjms.v17i2.35869.

24. Bakar A, Kurniawati ND, Laily H. Islamic Nursing Process in Fulfilling Immobilized Patients' Spiritual Need (Prayer). In: Iwasaki Y, Soebarniati R, Nursalam, Wijarnako B, Yusuf A, eds. The 1st International Nursing Conference (INC) Complementary Nursing Issues and Updates in 2015. Surabaya: Stikes Hang Tuah Surabaya; 2015:111-119. http://www.stikeshangtuah-sby.ac.id/wpcontent/uploads/2017/04/Proceeding-INC-1st-STIKESHang-Tuah-sby.pdf. 